\title{
DOCTORS IN THE PEOPLE'S REPUBLIC OF CHINA - AN OVERVIEW OF MEDICAL PRACTITIONER REGULATIONS
}

The People's Republic of China is a very big and diverse country with huge urban and rural populations. Providing such a number of people with even a basic healthcare coverage is challenging at the best of circumstances. This, combined with several thousand years of traditional medical practices, and a radical transformation the country has been undergoing for the last forty years creates a varied regulatory landscape. In this article, the author presents selected regulations concerning Chinese medical practitioners and a brief history of medicine in China. It begins by presenting the historical background of medicine in China - from the ancient to modern times. The historical part is followed by an overview of selected contemporary regulations on medical practitioners in the People's Republic of China such as practitioners' licensing, the role of Traditional Chinese Medicine, professional and tort liability of doctors. In this article, the author also presents the huge and resurgent influence of Traditional Chinese Medicine: its own separate Law, a path to full medical licence for $\mathrm{TCM}^{1}$ practitioners and the state placing it as a part of the larger health-care system.

\section{A brief history of medicine in China $^{2}$}

The history of medicine in China is long, spanning at least 23 centuries. The oldest known treatise - Huángdì Neijing ${ }^{3}$ - The Inner Canon of The Yellow Emperor is from the $3^{\text {rd }}$ century BCE. This medical text has been treated as the fundamental doctrinal source for Chinese medicine for over 2000 years. The book consists of two parts. The first - Suwen $^{4}$ (Basic Questions) covers the theory and diagnostic

1 When used in this article, TCM referes to Traditional Chinese Medicine.

2 The following chapter is based on: J. Fenby, The Penguin History of Modern China: The Fall and Rise of a Great Power, 1850-2008, $1^{\text {st }}$ ed., London 2008.

3 Chinese simplified (PRC): 黄帝内经, pinyin: Huángdì Nèijing, Chinese traditional: 黄帝內經, pinyin: Huángdì Nèijing.

4 Chinese: 素問, pinyin: Sù wèn. 
methods, the second Lingsbu (Spiritual Pivot) is about acupuncture. ${ }^{6}$ It is written in the form of a dialogue between Huangdi, legendary Yellow Emperor, and his physician, in which Huangdi inquires about the nature of health, disease, and treatment.

An imbalance of the two basic forces of nature - yin and yang - are the cause of illness. Medically speaking, everything could be classed either as yin or yang. To heal diseases, the ancient Chinese physicians were supposed to bring these two qualities back into balance. ${ }^{7}$ For example - inside of the body is generally yin (e.g. lungs, kidneys, spleen) and yang is the surface or skin. Diseases themselves can also be treated as yin and yang (yin - when caused by internal causes, yang when caused by external causes). ${ }^{8}$

Another tradition in Chinese medicine is the one of herbalism. Its foundational document was Shénnóng Běncǎo Jing, ${ }^{9}$ which unfortunately does not exist anymore. It is believed it was a compilation of oral traditions on agriculture and medicinal plants. The remedies were categorised according to the effect as superior, medium, and inferior. Superior remedies were non-poisonous and rejuvenating. Medium remedies had some toxicity based on the dosage and exerting tonic effects. Inferior remedies were poisonous but also helpful in reducing fever and curing indigestion. While the text was compiled in the early centuries CE, its title attributes it to another mythical Chinese emperor - Red Emperor Shennong - also known as the father of Chinese Medicine. ${ }^{10}$

Chinese medical tradition has its great physicians just as the Western one had Galen and Hippocrates. The first one of those whose work was not attributed to mythical emperors would be a Bian Qiao. He himself is more of a semi-mythical figure, who may have lived around $5^{\text {th }}$ century BCE, but his actual history is not well known. He serves more as an archetype of a good medic than a flesh-andblood historical figure, and stories about his deeds are used as instructive or cautionary tales.

${ }^{5}$ Chinese: 靈樞, pinyin: Ling shü.

${ }^{6}$ Traditional Chinese medicine [in:] Encyclopaedia Britannica, https://www.britannica.com/science/ traditional-Chinese-medicine (accessed: 5.01.2020).

7 The Yellow Emperor's Classic of Internal Medicine - US National Library of Medicine National Institutes of Health, https://www.ncbi.nlm.nih.gov/pmc/articles/PMC2287209 (accessed: 5.01.2020).

${ }^{8} \mathrm{Fu} \mathrm{Xi}$, the legendary founder of Chinese people, created the Bagua. It consists eight trigrams/three-line symbols, composed of continuous and broken lines. The continuous lines are known as yang - they represent male aspects of life, the broken lines - yin - represent female aspects of life. This is one of the fundamental concepts of the Chinese philosophy.

9 Simplified Chinese (PRC): 神农本草经, pinyin: Shénnóng Bèncáo Jing; traditional Chinese: 神曹本草, pinyin: Shénnóng Bèncǎo Jing.

${ }_{10}$ Traditional Chinese medicine, Fu Xi and the bagua - Encyclopaedia Britannica; https://www.britannica.com/science/traditional-Chinese-medicine/Fu-Xi-and-the-bagua\#ref282574 (accessed: 5.11.2019). 
A definitely flesh-and-blood practitioner of medicine with indisputably attributable legacy would be the so-called Hippocrates of China, Zhang Zhongjing, who lived in the latter days of the Han dynasty ( 150- 220 CE). However, probably a more apt Western comparison would be to Galen, due to the fact of the lasting impact of his prolific writing on Eastern medicine. Zhang Zhongjing left several treatises about diet, illnesses, and cures. He was advocating to avoid overusing remedies on patients that could actually make them worse. He also left important remarks on typhoid and fever treatments in general, advocating cooling baths, which was unheard of before, and not a practice in the Western medical tradition until 18-hundreds. His work was analysed, compiled and re-used for more than a thousand years.

Another mention would be Hua Tuo, a contemporary of Zhang Zhongjing. He has become famous as a skilled surgeon in the medical tradition that did not take surgery seriously. He also created an early attempt at what would nowadays be called physiotherapy, prescribing his patients exercises mimicking the postures of animals (e.g. tiger, deer, bear, ape, and bird). While his surgical knowledge was largely forgotten after his death, the other aspects, especially the exercises had a more lasting impact on the development of Chinese medicine.

Whang Shuhe created or perfected the art of diagnosis based on the examination of patient's pulse, while Ce Hong made some observations about the nature of smallpox in the $3^{\text {rd }}$ century CE.

One more notable development would be inoculations against smallpox practised in Asia since $c a$. the $10^{\text {th }}$ century CE. We do not know who was the inventor of the technique of inhaling dusted scabs. While it can hardly be called a vaccine, the practice is said to have reduced mortality rates significantly where applied.

The period between the $3^{\text {rd }}$ and $16^{\text {th }}$ centuries is characterised more by attempts to systematise the knowledge than by any particular breakthroughs. The practice of surgery became the paradoxical victim of the Confucian principle of non-violence that saw that kind of interference in the body as something best to be avoided.

The first lasting contact with the European medicine was established when the bishop of Macau, Jesuit priest, Belchior Miguel Carneiro Leitão, ${ }^{11}$ opened St Raphael's Hospital in Macau in the second half of the $16^{\text {th }}$ century.

Western medicine started gaining popularity at the cost of local traditions, especially in the late Qing period, when, after the enormous crisis of the $19^{\text {th }}$ century, the ruling dynasty tried to reform the country westernising many aspects of its life, medicine included. The abolition of the monarchy and the proclamation of the republic was supposed to establish the era of constitutional rule in the country. However, even though the interim president of the new republic was himself a trained

11 H. Brock, Melchior Carneiro [in:] The Catholic Encyclopedia, vol. 3, New York 1908, http://www. newadvent.org/cathen/03370a.htm (accessed: 26.11.2019). 
doctor, Sun Yat-Sen had more pressing matters to attend to than health policy, and his successor, Yuan Shikai, was keen on restoring the monarchy with one crucial change, him as an emperor. Soon after the chain of events led to the onset of the tensions, multiple government centres, and finally an all-out civil war, that devolved any central power into the hands of provincial warlords. This was not the environment for any sort of coherent healthcare policy to emerge. However, in the 30-ties, the Rural Reconstruction Movement, led by, inter-alia, neo-Confucian, philosopher Liang Shuming ${ }^{12}$ pioneered the idea of providing basic healthcare to rural regions of the country by providing the villagers with basic medical knowledge and training in skills relating to ambulatory medicine, and treatments for the most common afflictions and diseases. The concept of a barefoot doctor was born, in practice, if not in the name just yet.

After the civil war and the proclamation of the People's Republic of China, healthcare was left in the hands of the provincial governments, with various experiments in the expansion of primary healthcare into underserved rural areas. What is now known as the 'barefoot doctor" ${ }^{13}$ program did not get started in 1965, but was rather the mix of those experiments. The program, however, got prominence and became state-wide with the full support of Chairman Mao, who vehemently criticised disparities between rural and urban access to healthcare. A typical 'barefoot doctor' got mixed training of both traditional Chinese practices, like acupuncture, and basic modern medical training, focusing on disease prevention and prophylaxis. Those practitioners were organised into Rural Co-operative Medical Schemes, the idea, never fulfilled, was to train one barefoot doctor per thousand citizens. The program became a part of the Cultural Revolution and that, in a way hurt the idea, entangling the program in the fight over the influence of the Ministry of Health. The barefoot doctor program radically increased the coverage and access to basic medical services in areas where it had not been possible before. It reduced infant mortality and resulted in longer lifespans. It was also widely successful in the international propaganda sense. ${ }^{14}$

The program was cancelled in 1985 , but in practice, the coverage started shrinking as early as 1981. It was the result of creating the institution of the village doctor and a general retreat from the highly collective nature of the old program. However, the newer, more market-oriented program resulted in reducing the coverage drastically early on. The situation got better in the early 2000 s, when the New Rural Co-operative Medical Schemes were introduced, in the aftermath

12 Liang Shuming Chinese philosopher [in:] Encyclopaedia Britannica; https://www.britannica.com/ biography/Liang-Shuming (accessed: 12.11.2019).

13 Chinese: 赤脚医生, pinyin: chijižo yishèng - literally meaning 'barefoot doctor.'

14 Daqing Zhang, China's barefoot doctor: past, present, and future, “The Lancet," 20.10.2008, https://www.thelancet.com/journals/lancet/article/PIIS0140-6736(08)61355-0/fulltext (accessed: 26.11.2019). 
of the late nineties SARS epidemic. It resulted in a massive expansion of basic healthcare coverage.

The 2010s brought a new push for re-introducing Traditional Chinese Medicine, engaging the state in a widespread promotion and embrace of TCM. In 2018, the World Health Organisation adopted statistic codes for TCM diagnosis, implicitly legitimising the practice internationally. ${ }^{15}$

\section{An overview of regulations}

The Law of the People's Republic of China on Medical Practitioners ${ }^{16}$

Currently, the most important regulation for medical practitioners is the Law of the People's Republic of China on Medical Practitioners. It has been adopted at the $3^{\text {rd }}$ Meeting of the Standing Committee of the Ninth National People's Congress on June 26, 1998, and promulgated by Order No. 5 of the President of the People's Republic of China on June 26, 1998. Those regulations have entered into force as of May 1, 1999. ${ }^{17}$

According to article 1, this law was enacted for strengthening a contingent of doctors, improving their professional ethics and calibre, safeguarding their lawful rights and interests and protecting the people's health. ${ }^{18}$ This Law is applicable to professional medical workers, who are qualified to practice medicine. Doctors referred to in this Law include assistant medical practitioners and medical practitioners. It is also worth noting that the Law, literally states that the whole society should respect doctors.

To become a medical practitioner or to become an assistant medical practitioner they are obliged to pass a state exam. The exam is divided into two tiers: for practising doctors and assistant doctors. The examination for the qualifications of doctors shall be arranged by the administrative departments for public health of the people's governments at or above the provincial level (article 8).

Participation in the state exam for medical practitioners is allowed under conditions stated in article 9 which are as follows:

15 ICD-11; International Classification of Diseases $11^{\text {th }}$ Revision, https://icd.who.int/en/ (accessed: 14.01.2020).

16 Chinese: 中华人民共和国中医药法, pinyin: Zhōnghuá rénmín gònghéguó zhōngyāyào fă.

17 Law of the People's Republic of China on Medical Practitioners - Asian Legal Information Institute, http://www.asianlii.org/cn/legis/cen/laws/lotprocomp511/ (accessed: 6.01.2020).

18 Article 1 Law of the People's Republic of China on Medical Practitioners, http://www.npc. gov.cn/zgrdw/englishnpc/Law/2007-12/11/content_1383574.htm (accessed: 6.11.2019). 
- having, at least, graduated from the faculty of medicine of a university and, under the guidance of a licensed doctor, worked on probation for at least one year in medical treatment, disease-prevention or healthcare institution;

- after obtaining the license for an assistant doctor, having reached the level of a graduate from the faculty of medicine of a university and worked for at least two years in a medical treatment, disease-prevention or healthcare institution; or having reached the level of a graduate from the speciality of medicine of a polytechnic school and worked for at least five years in a medical treatment, disease-prevention or healthcare institution.

Those who have medical degrees from technical secondary schools or 3-year medical colleges can take an examination for assistant practising doctors' qualifications after a probation period - one year or more under the supervision of practising doctors in a hospital or other health care facility.

What is also worth mentioning is allowing the practitioners of traditional Chinese medicine to access those exams if they have learned from masters for three years or have acquired special medical skills through many years of practice. They need to be assessed and recommended by professional associations of traditional medicine, approved by the health administration departments of the people's governments at or above the county level, or institutions for medical treatment, disease prevention or healthcare. Article 11 shows how much Traditional Chinese Medicine (TCM) is an integral part of Chinese healthcare. Traditional Chinese doctors and practitioners of modern medicine are subject to the same set of regulations regarding education, licensing and continuous education.

Traditional Chinese Medicine, with a history of more than 2,000 years, is seen by many as a national treasure for its unique theories and practices, such as herbal medicine, acupuncture, massage and dietetics. 'Traditional Chinese medicine is an integral part of Chinese healthcare. Traditional Chinese doctors and practitioners of modern medicine are subject to the same set of regulations regarding education, licensing and continuous education. ${ }^{19}$ All Traditional Chinese Medicine practitioners must pass tests. Apprentices may only begin practice when they have recommendations from at least two qualified practitioners and pass relevant tests.

Chapter 5 of the Law of the People's Republic of China on Medical Practitioners deals with legal responsibility. The first one - article 36 is about getting a doctor's license by illegitimate means. In such a case, the administrative department for health that granted the license shall revoke it. The persons, who are directly in charge, and the persons who are responsible for it, shall be given administrative sanctions. A disciplinary warning or order to suspend the practice (suspension lasts

19 M. Oravecz, H. Kuang, J. Mészáros, Education and licensing of traditional Chinese doctors in China, "Borgis - New Medicine" 2011/1, pp. 30-34, http://www.czytelniamedyczna.pl/3686,educationand-licensing-of-traditional-chinese-doctors-in-china.html (accessed: 9.11.2019). 
from 6 months to 1 year) shall be given to any doctor who has violated the provisions of this Law. In case when the circumstances are serious, the license for medical practice shall be revoked. Article 37 defines a list of situations when doctors may be investigated and prosecuted according to this Law in case of criminal offences:

- causing serious consequences by violating the administrative rules, regulations for public health or the rules for technical operation;

- a medical accident caused by the negligence of medical duties;

- serious consequences caused by the negligence of duties and delaying the rescue, diagnosis and treatment in an emergency case;

- signing a document concerning treatment, birth certificate or death certificate without proper examination or investigation;

- hiding, forging or destroying medical documents and relevant data;

- using medicines, and medical equipment that has not been approved;

- failing to use narcotic drugs, toxic medicines, medicines for mental disorder and radioactive medicines in accordance with the rules;

- conducting experimental clinical treatment on a patient without the consent of the patient or the family thereof;

- causing serious consequences by divulging the patients' privacy;

- abusing their position to seek material gains or other illegitimate benefits;

- failing to accept the assignment of the administrative department for public health under the circumstances of natural calamities, epidemics, sudden accidents resulting in heavy casualties or other emergencies which seriously endanger people's lives or health;

- failure to report a medical incident, or discovering an epidemic, or a patient who is involved in an incident of injury or unnatural death.

It is forbidden to practice medicine without a valid licence or to set up a medical institution without valid permission. Such cases will result in confiscation of unlawful gains, medicines, medical equipment, and shall also result in a fine of up to 100,000 CNY. It can also result in criminal responsibility (article 39).

On the other hand, doctors are protected by law and any attempt at slander, humiliation, or violence directed at the lawfully practising doctors shall be treated as an offence, or in more serious circumstances, a crime (article 40). Article 41 creates a general criminal sanction for failing the informational duties mentioned in article 16 (i.e. not reporting to the responsible officials circumstances when a practitioner is not able to lawfully practice medicine, e.g. his/her death or being imposed on criminal or administrative punishment). Article 42 forbids and sanctions with criminal or administrative punishments misconduct of any kind (e.g. fraud, bribery, negligence, abuse of power) that may constitute a crime or administrative offence on the part of any member of the state's healthcare system, both administrative and medical (treatment, disease prevention, or general healthcare institutions). 
The Traditional Chinese Medicine Law

of the People's Republic of China ${ }^{20}$

The Traditional Chinese Medicine Law of the People's Republic of China has been enacted on December 25, 2016 and came into force on July 1, 2017..$^{21}$ It is a relatively new and rather important element of Chinese push for broader adoption of Traditional Chinese Medicine ${ }^{22}$ internally and internationally. The Law provides a basic regulation for managing and expanding a network of practitioners and clinics across the whole country. It also obliges local governments to plan the expansion of TCM healthcare services and institutions in their areas (article 11). The law also states that any attempt at reorganisation, merging, or any other change in the structure of an existing medical institution require the opinion of a higher-level department of health. General norms on promoting and expanding the access to TCM healthcare are instituted, generally placing it on an equal footing with western medicine.

The relationship between western medicine and TCM as equal priorities for the government is established in article 3. It encourages both traditions to learn from one another. Articles 7-8 state that proper education system shall be established for teaching and talent development in the TCM area, and grants the state's support for research and technological development of TCM practices and remedies. This includes expanding intellectual property rights. Article 9 obliges the states to promote and disseminate TCM internationally.

In chapter 2, the Law states that the state is responsible for providing the TCM services to citizens, obliges the existing hospitals, clinics, and village clinics run by the government to set up the TCM departments (article 12). The establishment of those departments, clinics, and other medical institutions and personnel hired there are subject to the norms and rules set by the state and subject to review and approval by the government (articles 13-20).

Chapter 3 sets the basis for the regulatory framework for obtaining and protection of supply of necessary ingredients, including protection of wild animals and plants. Organising a proper and legitimate market of ingredients, with proper sourcing, history and traceability is also in scope. The proposed system makes an exception for self-grown herbs of TCM practitioners working in village medical institutions.

\footnotetext{
20 Chinese: 中华人民共和国中医药法, pinyin: Zhōnghuá rénmín gònghéguó zhōngyīyào fă.

${ }^{21}$ Traditional Chinese Medicine Law of the People's Republic of China, http://fjs.satcm.gov. cn/zhengcewenjian/2018-03-24/2249.html (accessed: 12.01.2020).

22 Traditional Chinese Medicine in China, The State Council Information Office of the People's Republic of China, December 2016, First Edition 2016, http://english.www.gov.cn/archive/white_paper/2016/12/06/content_281475509333700.htm (accessed: 12.11.2019).
} 
It is also worth noting that article 29 obliges the state to support the development and production of new TCM recipes, the 'modernisation' of traditional recipes (e.g. by using modern measures instead of traditional ones). The following article reduces the burdens on registration on TCM drugs developed on the basis of ancient, long-standing recipes, provided the recipes in question are on the special list maintained by the State Council. Article 32, besides the regulatory requirements for recipe registration, obliges the medical institutions to watch for and monitor the cases of an adverse effect of the concoctions given to their patients.

Chapter 4 sets the rules for the training of new TCM practitioners, it obliges the state to set up a network of schools and necessary examinations. The approach of combining both western and TCM knowledge is advised and viewed as a benefit.

Chapter 5 advocates the progress and scientific research in the area of TCM, integration of TCM and western medicine, and the promotion of TCM knowledge. It encourages the donation of privately held TCM sources of information to the state (e.g. literature, recipes, diagnostic methods) (article 39).

Chapter 6 contains the rules regarding treating the TCM recipes as cultural heritage. The norms regarding setting up the chains of 'inheritance' of knowledge, state obligation to organise proper training and maintaining the use of TCM practices among the society. The following articles advocate setting up universal standards of care. It is notable that the chapter concerning keeping the knowledge alive and the promotion of such knowledge, ends with article 46 that basically bans any kind of 'false-promises' advertisement of TCM practices and remedies. However, the same article states that such promotion should be done with the employment of experts in the field.

Chapter 7 of the Law contains the norms regarding setting up standards of care, setting up the framework for proper health insurance coverage (TCM procedures shall be included in basic insurance packages). The standards shall be set by the relevant departments of the State Council. It is worth noting here, that medical practices of ethnic minorities, their medical knowledge, and heritage shall be treated as worth special protection of the state (article 52).

Chapter 8 of the Law deals with legal responsibility. It creates a set of rules for the state to monitor and punish abuses of a licence to practice TCM, both at an institutional (article 54) and individual level (article 55). There are also criminal punishments for using improper or fake ingredients in decoctions and medicines. Those punishments contain also banning the practice for five years on the offending practitioner, monetary punishments, and sanctions up to revoking the licence altogether. There are also special sanctions on the parties using not allowed pesticides of high toxicity on the plantations of TCM herbs. The punishment may include, inter alia, detention of 5-15 days (article 55). Article 57 deals with an advertisement that is not compliant with the Law and states that the offending party may be withheld from the right to advertise for the duration of 1 year. It also contains the 
provision subjecting the TCM ads to general rules of Advertising Law. The chapter ends with article 59, the general clause that subjects any party causing damage to a person or property to the general rules of civil and criminal law.

In the author's opinion, the development and legitimisation of TCM are problematic and raise several concerns. The Law uses the dichotomy of TCM and 'western' (i.e. conventional) medicine. This approach has issues. Firstly, even the naming convention suggests that conventional medicine is a product of foreign influence, possibly implying the element of mistrust in modern-day medical research. Secondly, it puts TCM on an equal footing with the rest of the medicine, as a complete system of medical knowledge. While the author is far from the view that traditional practices should be frowned upon just because they are traditional, giving TCM such a position of privilege is risky at best. Incorporating great amount of untested and unverified practices as part of healthcare may have consequences ranging from creating false sense of healthcare coverage, syphoning the resources from development of conventional medical facilities, and making it hard to separate the truly useful traditional practices from those that probably should remain in the annals of history of medicine only. The author's view would be that TCM should be subjected to the same rigour of critical scientific research as any other kind of medical knowledge. Truly beneficial practices may that way be adopted into mainstream medicine and propagated around the world for the benefit of human knowledge as a whole.

The last, but definitely not least, of the concerns are not directly related to the healthcare system. China seems to be using TCM and its popularisation around the world as an element of soft-power and cultural significance issue. The legitimisation of TCM by WHO in ICD 11 will, in the author's opinion lead to a wider adoption of the practices worldwide. The concerns for the scientific validity of the practices prescribed by TCM aside, this creates the need for rare animal and plant ingredients, fuelling the black market for rare and endangered species, poaching around the world and general pressure on the environment. On the bright side, the Chinese authorities seem to notice the issue and react to it at least somewhat. ${ }^{23}$ The true results of the government's push to adopt TCM more broadly are yet to be seen and it will be interesting to watch if the net results of the regulation described above are positive.

${ }^{23}$ R. Bale, Pangolin scale medicines no longer covered by Chinese insurance, "National Geographic," 29.08.2019, https://www.nationalgeographic.com/animals/2019/08/pangolin-traditional-medicine-not-covered-insurance/ (accessed: 26.01.2020). 
The Tort Liability Law of the People's Republic of China was adopted at the $12^{\text {th }}$ session of the Standing Committee of the Eleventh National People's Congress on December 26, 2009. Those regulations have entered into force as of July 1, 2010.

This Law was enacted in order to protect the legitimate rights and interests of parties in a civil law relationship, prevent and punish tortious conduct, clarify tort liability. It was also created to promote social harmony and stability. It covers the area of torts including personal injury and medical malpractice, damage to the environment and even the legal liability of individuals who rear animals. ${ }^{25}$ Before 1980 , in the People's Republic of China there was no legal concept of 'tort.' The Tort Law mentioned below was influenced in part by foreign legal systems.

The Tort Liability Law contains 12 chapters and 92 articles. 'It discusses general tort principles, including rights and interests, criteria for liability, damages and compensation and mental damages, as well as specific tort fields, such as product liability, Internet service provider liability, medical malpractice, and liability for environmental pollution. ${ }^{26}$

In this article, the author will deal with regulations contained in chapter VII Liability for Medical Malpractice, which contains articles 54-64. First, article 54 states: if any medical organization or its medical personnel is responsible for damage inflicted on a patient during the course of diagnosis and treatment, the medical organization shall be liable for compensation. This sets a general rule for liability in case of medical malpractice. The following articles built on this general rule add examples of possible malpractice. There are several possible situations when medical institutions may be at fault for damage to a patient:

- failing to inform the patient about the course of diagnosis and treatment, medical risks, and alternative treatment plans;

- failing to obtain written consent of the patient or, where obtaining the former is impossible, written consent of his or her immediate relatives;

- failing the informational obligations or not obtaining consent cannot be treated as malpractice when medical procedures were due to an immediate emergency;

- not following standards of care (articles 55-57).

A medical organisation shall be presumed to be at fault if the damage is inflicted under the following circumstances:

${ }^{24}$ Chinese simplified: 中华人民共和国侵权责任法, pinyin: Zhōnghuá rénmín gònghéguó qinquán zérèn fä.

25 Ch. Wang, N.H. Madson, Inside China's legal system, Oxford 2013, pp. 151-154.

${ }_{26}$ Tort Liability Law of the People's Republic of China, commentary from law firm Faegre Baker Daniels, https://www.faegrebd.com/en/insights/publications/2010/2/tort-liability-lawof-the-peoples-republic-of-china (accessed: 9.11.2019). 
- violation of laws, administrative regulations, rules or other relevant requirements for diagnostic and treatment practices;

- concealment of or refusal to provide medical records related to the dispute,

- forgery, falsification, or destruction of medical records (article 58).

In case of damage caused by defective drugs, disinfectants or medical devices, or from transfusing blood that does not meet certain standards, the patient might seek compensation from both - manufacturer or blood-supplying organization, and the medical organisation. In such a case, a medical organisation is entitled to claim reimbursement from the manufacturer or the blood-supplying organization liable for the damage after compensation (article 59). A medical organization shall not be liable for compensation under the following circumstances:

- refusal to cooperate with the medical organization by the patient or his or her immediate relatives in diagnosis and treatment that comply with standards of care. In case when a medical organization and its personnel are also at fault, the medical organization shall bear the corresponding compensation liability.

- difficulties in diagnosis and treatment caused by prevailing medical standards;

- following the appropriate procedures in case of emergency (e.g. resuscitation) (article 60).

Medical institutions and medical professionals are obliged to keep and preserve hospital admission records, laboratory test reports, doctors' instruction sheets, surgical and anaesthesia records, health care records, pathology data, medical cost records and other medical records. Medical institutions and medical professionals are obliged to maintain the privacy and confidentiality of patients, they are also obligated not to carry out unnecessary exams or other procedures in violation of clinical norms (articles 61-63).

The chapter on medical malpractice ends with article 64 which grants the full protection of the law to legitimate rights and interests of medical organizations and personnel and threatens with legal liability anyone who would interfere in medical administration or hinder the work or lives of medical personnel.

The Law of the People's Republic of China on Basic Healthcare and Health Promotion ${ }^{27}$

The proposal of the Healthy China Initiative was a milestone in China's health policy and health reform. The Law of the People's Republic of China on Basic Healthcare and Health Promotion was adopted on December 28, 2019, those regulations will enter into force as of June $1,2020 .^{28}$

\footnotetext{
27 Chinese: 中华人民共和国基本医疗卫生与健康促进法, pinyin: Zhōnghuá rénmín gònghéguó jībèn yiliáo wèishèng yǔ jiànkeang cùjìn fă.

${ }_{28}$ China People's Congress Network (untitled press information), http://www.npc.gov.cn/ wszb/wszb8/zzzb8.shtml (accessed: 13.01.2020).
} 
This Law is enacted in order to help develop medical and health undertakings, guarantee citizens' access to basic medical and health services, improve citizens' health, and promote public health in China. The state implements a 'healthy China' strategy, popularizes healthy living, optimizes health services, improves health guarantees, builds a healthy environment, develops health industries, and improves citizens' health throughout the life cycle. The state establishes a health education system, guarantees citizens' right to health education, and improves citizens' health literacy. ${ }^{29}$ This Law regulates comprehensively Basic Medical and Health Services, Medical and Health Institutions, Medical Staff, Guarantee of Drug Supply, Health Promotion, Guarantee of Funds, Supervision and Management and Legal Liability.

\section{Conclusion}

Chinese civilisation has a long medical tradition and legacy. Modern China is not abandoning its practices and believes fundamental to Traditional Chinese Medicine. Currently, existing regulations can be seen as an attempt at striking a balance between ancient traditions and modern medicine. Traditional Chinese Medicine is considered a part of national heritage, and with the push for adoption and popularisation of TCM in China and abroad, it is finding its way into modern-day medicine with the full support of the People's Republic government. The result of this mixture is yet to be seen. Is the push for TCM an honest attempt in providing a mix of modern and traditional remedies to a broader population or just a placebo meant to mask the failings of the healthcare system at large?

The presented laws and regulations are a part of a bigger, constantly changing and developing system that transitioned from total socialisation and nationalisation to a more market-oriented, insurance-based system that left many people without access to a doctor. The sheer size of the country, its diversity, and disparities between urban centres and under-developed rural areas make any attempt at providing healthcare tricky at best.

29 Xinhua Net press release containing the text of the Law, http://www.xinhuanet.com/ politics/2019-12/28/c_1125399629.htm (accessed: 26.01.2020). 
STRESZCZENIE

\title{
LEKARZE W CHIŃSKIEJ REPUBLICE LUDOWEJ - PRZEGLĄD REGULACJI DOTYCZĄCYCH PRAKTYKOWANIA MEDYCYNY
}

\begin{abstract}
Medycyna w Chinach ma bardzo długą historię, sięgającą czasów starożytnych. Współcześnie w Chińskiej Republice Ludowej można zaobserwować tendencję do powrotu i promocji medycyny tradycyjnej na równi z medycyną konwencjonalną do tego stopnia, że została ona uregulowana w odrębnej ustawie. Co istotne, osoby zajmujące się medycyną tradycyjną moga, po zdaniu odpowiednich egzaminów i spełnieniu określonych warunków, zdobyć uprawnienia lekarskie na równi z absolwentami studiów medycznych. W artykule na podstawie wybranych ustaw przedstawiono niezwykle złożony i różnorodny system praw i obowiązków, którym podlegają lekarze i urzędnicy zajmujący się ochroną zdrowia publicznego.
\end{abstract}

